\title{
ENTREPRENEURSHIP AND SOCIAL CAPITAL: EXAMINING THE ASSOCIATION IN DEPRIVED URBAN NEIGHBOURHOODS
}

\author{
Nick Williams \\ Centre for Enterprise and Entrepreneurship Studies, University of Leeds, 17 Springfield \\ Mount, Leeds, LS2 9NG, UK \\ n.e.williams@leeds.ac.uk \\ Robert Huggins \\ School of Planning and Geography, Cardiff University, King Edward VII Avenue, Cardiff, \\ CF10 3WA, UK \\ hugginsr@cardiff.ac.uk

\section{Piers Thompson} \\ Economics Department, Nottingham Business School, ${ }^{\text {th }}$ Floor Newton Building, \\ Nottingham Trent University, 50 Shakespeare Street, Nottingham, NG1 4BU \\ piers.thompson@ntu.ac.uk
}

\begin{abstract}
Spatial approaches to examining entrepreneurship have increasingly built on theories of social capital. However, the nature and extent of local social capital in less successful deprived communities remains under-researched and inadequately understood. The paper examines the association between social capital and entrepreneurship in a deprived urban neighbourhood in the city of Leeds, UK as a means of contributing to an improved theoretical understanding of how space moderates this association. It is found that social capital has a strong association with patterns of entrepreneurship in deprived urban neighbourhoods, with the potential impacts being both positive and negative. The forms of social capital are found to differ from that found in more affluent localities, with a prevalence of bonding social capital as the key facilitator of entrepreneurship, which may help in the early stages of venture development, but which over time may become a constraint. Also, a lack of the bridging social capital associated with entrepreneurial success is found within the locality. From a policy perspective, it is recommended that policy makers responsible for entrepreneurship in deprived urban neighbourhoods should seek to enhance initiatives for developing social capital which incorporate local businesses, residents and local government agencies.
\end{abstract}

Key words: entrepreneurship; social capital; deprived urban neighbourhoods

Please cite this article as follows:

Williams, N. Huggins, R. and Thompson, P. (2018) 'Entrepreneurship and social capital: examining the association in deprived urban neighbourhoods', International Journal of Urban and Regional Research, doi: 10.1111/1468-

2427.12589

which has been published in final form at:

http://dx.doi.org/10.1111/1468-2427.12589

This article may be used for non-commercial purposes in accordance with Wiley Terms and Conditions for Self-Archiving. 


\title{
ENTREPRENEURSHIP AND SOCIAL CAPITAL: EXAMINING THE ASSOCIATION IN DEPRIVED URBAN NEIGHBOURHOODS
}

\begin{abstract}
Spatial approaches to examining entrepreneurship have increasingly built on theories of social capital. However, the nature and extent of local social capital in less successful deprived communities remains under-researched and inadequately understood. The paper examines the association between social capital and entrepreneurship in a deprived urban neighbourhood in the city of Leeds, UK as a means of contributing to an improved theoretical understanding of how space moderates this association. It is found that social capital has a strong association with patterns of entrepreneurship in deprived urban neighbourhoods, with the potential impacts being both positive and negative. The forms of social capital are found to differ from that found in more affluent localities, with a prevalence of bonding social capital as the key facilitator of entrepreneurship, which may help in the early stages of venture development, but which over time may become a constraint. Also, a lack of the bridging social capital associated with entrepreneurial success is found within the locality. From a policy perspective, it is recommended that policy makers responsible for entrepreneurship in deprived urban neighbourhoods should seek to enhance initiatives for developing social capital which incorporate local businesses, residents and local government agencies.
\end{abstract}

Key words: entrepreneurship; social capital; deprived urban neighbourhoods

\section{INTRODUCTION}

Spatial approaches to examining entrepreneurship and community development have increasingly built on theories of social capital (Westlund and Bolton, 2003; Onyx and Leonard, 2010; Murphy et al, 2015). Social capital focuses on the significance of social relations developed through personal contacts, networks and norms of behaviour (Welter et al, 2008). It can be defined as "the ability of individuals to secure benefits as a result of membership in social networks or other social structures" (World Bank, 2000, p. 128), and is increasingly regarded by policy makers and theoreticians as "an antidote to a range of social ills and its absence as a cause of those same ills" (Johnston and Percy-Smith, 2003, p. 321). The power of the social capital concept is its ability to understand how individuals are able to mobilize their network to enhance personal returns usually within place-bound environments.

Although earlier studies of entrepreneurship focused on the impact of human capital and environmental factors, work over the last 20 years has begun to accommodate the impact that social capital and network ties play. In both generating entrepreneurial intentions (Liñán and Santos, 2007) and the instigation and progression through the business start-up process (Johannisson, et al. 2002; Davidsson and Honig, 2003) social capital is suggested to play an important role in supporting entrepreneurs both emotionally and practically (Grant and Baden-Fuller 2004). In this sense, social capital is essentially a place-based social network phenomenon (Westlund and Bolton 2003; Staber, 2007). It is argued that the existence of social capital is a key reason why a number of the most successful localities throughout the world have become or remained more economically competitive (Huggins, 2010; Huggins and Johnston, 2010). However, the nature and extent of social capital remains poorly understood (Evans and Syrett, 2007). Furthermore, whilst the concept has increasingly become recognized as a place-based phenomenon, many of the scholarly endeavours in the field have focused on studies linking social capital to the performance of high-economically performing and affluent local environments, 
rather than the lower performing and economically deprived communities that continue to exist within most advanced economies (Westlund and Bolton 2003). As Staber (2007) states, the role of social capital has often neglected the situational contexts in which it evolves. In particular, the nature and extent of local social capital resources in deprived communities remains under-researched and inadequately understood, especially due to the lack of more interpretative and contextual studies (Middleton et al, 2005). As Forrest and Kearns (2001, p. 2131) state: "we remain relatively ignorant ... about differences in contemporary patterns of local interaction within different types of neighbourhoods".

Understanding social capital and its role in deprived urban neighbourhoods has the potential for helping to improve economic and social outcomes. Porter (1995: 55) states that "the lack of businesses and jobs in disadvantaged urban areas fuels not only a crushing cycle of poverty but also crippling social problems." Yet successive governments have sought to tackle and alleviate these issues, part of which has been through policies aimed at promoting entrepreneurship (Huggins and Williams, 2009). Policy has focused on the "entrepreneurial city" which has emerged as a response to urban problems such as high levels of crime, poorer health, environmental degradation and poorer housing in deprived localities (Corcoran, 2006). In the UK, localized areas of disadvantage are persistent due to: first, a weak economic base, with barriers to work for individuals, poor skills or connectivity or factors discouraging business investment; second, poor housing and local environments and unstable communities, characterized by concentrations of poor vulnerable residents, high levels of disorder and antisocial behaviour, and poor physical connectivity with labour markets; and thirdly, poor performing public services and delivery of support to deprived areas (Chatterton and Bradley, 2000; Williams and Williams, 2011). Deprived urban neighbourhoods in the UK exhibit stubborn rates of unemployment, high levels of worklessness and benefits dependency, and mobility is often low, meaning that residents do not seek to obtain work elsewhere (Fletcher, 2008). They also display low levels of entrepreneurship, and the relationship between deprivation and entrepreneurship has been the subject of study for a number of years (Williams and Williams, 2011). Policy makers often seduced by the desire to harness the 'entrepreneurial pixie dust that makes some cities sparkle with success, as others rust under the weight of excessive regulation' (Peck, 2016: 18). Yet reversing historically low levels of entrepreneurship in deprived urban environments brings significant challenges.

At the outset it is important to define what we mean by entrepreneurship. Although it is often defined as the foundation of new businesses, the concept is increasingly being defined and applied in several contexts (Westlund et al, 2014). However, for the purposes of this study we limit ourselves to analysing entrepreneurship in the form of start-ups. The aim of this paper is to provide a contribution to help fill the gaps in understanding between entrepreneurship, social capital and deprived urban neighbourhoods by examining the association between social capital and entrepreneurship in a deprived urban locality. This paper adds to emerging evidence that entrepreneurship is tied to the phenomenon of local social capital, and shows the link between social capital in the form of local network ties and the prevailing local entrepreneurial activities and perceptions. In addition, it demonstrates that there is a tension between the forms of network ties and the mechanisms and levers of entrepreneurship. In deprived communities, the prevalence of highly bonded ties can act as drag chains on the entrepreneurial process, and these drag chains stem from local evolutionary forces that can be related to theories of 'generation' and 'collective memory' (Lippmann and Aldrich, 2015). Fundamentally, it can be argued that at the local level places evolve through 'generational units' that often results in these places maintain similar rates of entrepreneurship over time (Fritsch and Mueller, 2005). Furthermore, these generational units become manifest at particular points in time through the underlying socio-spatial culture of places, which encompasses the broad community level mindsets at play within these places (Huggins and Thompson, 2015; 2016). 
Therefore, we posit that local entrepreneurial social capital is a factor tightly connected with the community culture, and the evolution of this culture, at a place-based level.

In particular, the paper seeks to address the following questions as a means of contributing to an improved theoretical understanding of how space moderates the association between entrepreneurship and social capital: (1) to what extent does social capital facilitate or constrain entrepreneurship in deprived urban neighbourhoods; (2) what forms of social capital impact upon entrepreneurship within these neighbourhoods; and (3) to what extent do deprived urban neighbourhoods moderate different types of social capital and entrepreneurship compared with more affluent localities. The concept of social capital has evolved to mean different things to different disciplines (Middleton et al, 2005), and in this paper we have reduced it to the key element of its original meaning - i.e. the nature of social relations - and we explore how these relations impact on entrepreneurship. It is found that social capital does have a strong association with patterns of entrepreneurship in deprived urban neighbourhoods, with the potential impacts being both positive and negative. The forms of social capital are found to differ from that found in more affluent localities, with a preponderance of bonding social capital as the key facilitator of entrepreneurship, which may help in the early stages of venture development, but which over time may become a constraint. Whereas bridging social capital has been found to be a key facilitator of entrepreneurship in more affluent localities, deprived urban neighbourhoods are characterized by a lack of such capital, and may also lack linking social capital due to a lack of trust in formal institutions such as banks and forms of business support (Stretzer and Woolcock, 2004). These findings contribute to the discourse on social capital with a deeper and more contextualized understanding (Staber, 2007) regarding how the nature of localities impacts upon their propensity to generate entrepreneurship.

The remainder of the paper is set out as follows. In the first section, the literature on entrepreneurship and social capital is examined, while the second section builds on this by focusing on deprived urban neighbourhoods. The third section reports the findings of a face-to-face survey with the residents (people who currently run a business or plan to start up in future) and follow-up in-depth interviews with entrepreneurs operating in a deprived urban locality within the city of Leeds, which is situated in the north of England and was previously an industrial centre but has evolved into a post-industrial urban economy with stark economic and social inequalities between affluent and deprived areas (Williams and Williams, 2011). The paper then reflects on the findings and provides conclusions from the context of future policy development.

\section{ENTREPRENEURSHIP, SOCIAL CAPITAL AND PLACE}

Entrepreneurship is frequently recognized as a crucial element in fostering economic development and growth (Michael and Pearce, 2009). While many studies have focused on national levels and the impact of entrepreneurship, over the last decade research in the field "has focused increasingly on spatial aspects of entrepreneurship" (Welter et al, 2008, p. 109). Entrepreneurs are increasingly depicted as agents of economic and social change that develop communities, often enacting a collective identity that facilitates and shapes development (Lippmann and Aldrich, 2015). From both a spatial and temporal perspective, entrepreneurs have been further conceived as 'generational units' in the sense that they are agents who mould collective memories through space and time (Lippmann and Aldrich, 2015). At the city level entrepreneurs play a significant role in the development of their local economy yet have often been overlooked in analyses of development (Glaeser et al, 2010). Indeed, entrepreneurship is increasingly acknowledged as an important factor underlying uneven economic geographies (Huggins and Thompson, 2016). Whereas previous attempts to improve economic and social 
outcomes in deprived areas focused on urban regeneration and renewal, placing entrepreneurship at the heart of these strategies has become more common despite the scepticism of some policy makers about its ability to make an impact (Huggins and Williams, 2011). Policy makers often celebrate triumphant cities which are viewed as containing entrepreneurial dynamism such as London or New York, whereas cities in decline, such as Detroit, are defined in part by lacking this very dynamism (Peck, 2016).

Factors relating to economic conditions and the institutional environment, especially those concerning the legitimacy of entrepreneurship (Kibler et al, 2014) and the availability of social capital in the form of trust-based networks (Westlund et al, 2014) are an important determinant of rates of entrepreneurship (Huggins and Thompson, 2016). Spatial approaches to understanding entrepreneurship have increasingly embraced the concept of social capital (Kwon and Arenius, 2010). As De Carolis and Saparito (2006, p. 41) state, "entrepreneurship is a result of the interplay of environments (i.e. social networks) and certain cognitive biases in entrepreneurs". Entrepreneurship research emphasizes the ways in which individuals can take advantage of social networks to achieve their entrepreneurial goals (Hoang and Antonic, 2003). At different spatial levels, social capital can be seen as a community characteristic that facilitates or inhibits the kind of innovative, risk-taking behaviour that is part and parcel of entrepreneurship and in this respect social capital acts as part of the resource endowment and can be favourable or unfavourable (Westlund and Bolton, 2003). Social capital is commonly associated with the assets required to achieve or maintain an individual's or group's position within social structures and networks, through actions governed by social norms, rules and interactions (Bourdieu, 1986; Coleman, 1988). In terms of understanding the different forms such social capital may take it as necessary to delve further into the myriad of definitions that have been employed to identify and explain the phenomena that can be considered to constitute social capital (Sobel, 2002). For instance, Ostrom and Ahn (2003: 1) consider social capital as 'an attribute of individuals and of their relationships that enhance their ability to solve collective problems'. Coleman (1988: 98) concurs with this view stating that social capital exists in the 'relations among actors'. Similarly, other authors such as Conway and Steward (2009) consider social capital to be located in 'relationships'. Dasgupta (2003) views social capital as a 'system of interpersonal networks' and 'nothing more', and develops this statement by referring to a prerequisite for social capital as being the maintenance of trust that members of an interpersonal network have in each other. This maintenance is achieved by the 'mutual enforcement of agreements'. Developing the notion of agreement, Fountain (1998) considers efficient and effective networks to have the capability to resolve conflict. Dasgupta (2005), on the other hand, considers the quality of an interpersonal network to be dependent upon the use to which it is put. Others, like Fukuyama (2003: 1), define social capital as 'an instantiated informal norm that promotes cooperation'. Social capital is described by Coleman (1988) as not being a unitary entity, rather a number of different entities. Dasgupta (2003) also refers to the variety of forms of social capital. Similarly, Beugelsdijk and Van Schaik (2005) and Woolcock and Narayan (2000) allude to the multidimensional nature of social capital.

Communities may be strongly tied or rooted to prevailing economic culture or activity, e.g. communities of practice (Huggins and Thompson, 2015). In this sense, culture plays a role in the types of social capital present which in turn influences entrepreneurship within a place, with the availability of social capital mediating the relationship between local culture and entrepreneurship. This is not to infer that one community culture is necessarily 'superior' to another, in the sense that Bourdieu (1986) views some communities as having greater endowments of 'cultural capital', but that it will have different impacts dependent on the relationships between culture, social capital and entrepreneurship in a locality. 
Most discussions of social capital proclaim it an unqualified 'good', i.e. something to be maximized (Putnam, 1995; Adler and Kwon, 2002). However, social capital may also have a 'downside' in that strong, long-standing civic groups may stifle development by securing a disproportionate share of resources or inhibiting individual economic advancement by placing heavy personal obligations on members that prevent them from participating in broader social networks (Portes and Landolt, 1996; Woolcock, 2001). In addition, a member of a network could also potentially "free ride" or act opportunistically so that calculation displaces trust and reciprocity (Portes, 1998). As Adler and Kwon (2002) state, in tight-knit communities strong norms may dictate the sharing of resources among extended family members, which may, in turn, reduce the incentives for entrepreneurial activity and slow the accumulation of capital.

In its positive form, social capital is a value-creating phenomenon because it complements other factors such as labour and technical knowledge in the production of outputs and can be described as civic participation (Putnam, 1995) or entrepreneurial creativity (Jacobs, 1961). Individuals can take advantage of "strong ties" with family and friends, which create strong trust, and "weak ties" who are acquaintances, customers, suppliers or colleagues (Granovetter, 1973; Burt, 1992). Strong ties share the same knowledge and contacts as the individuals themselves, while weak ties are outside the individual's immediate circle of contact and are therefore a diverse and large source of advice and information (Bruderl and Preisendorfer, 1996). Through reciprocity, goodwill can be built up and utilized as a valuable resource (Adler and Kwon, 2002). This then enables communities with stocks of social capital to benefit from economic development (Putnam, 1995).

Within this, there are often considered to be two forms of social capital: "bonding" and "bridging" (Putnam, 1995; Welter et al, 2008). Bonding social capital refers to the close ties between homogeneous groups, such as close friends and business associates who share similar demographic characteristics (Putnam, 1995; Middleton et al 2005). Bonding social capital may be described as a situation whereby the relationships existing between a group of individuals (or within a community) enable them to 'get by' through maintaining their existence and status quo (Putnam, 2000; Woodhouse, 2006). Bridging social capital refers to the ties which connect people between socially heterogeneous groups (Putnam, 1995), for example groups from different ethnic and occupational backgrounds (Middleton et al, 2005), and is essentially a horizontal metaphor (Stretzer and Woolcock, 2004). Middleton et al (2005, p. 1716) state that the bridging dimension is important as individuals in deprived communities are "usually excluded - by overt discrimination or lack of resources - from the places where major decisions relating to their welfare are made." Putnam and Goss (2004) state that bridging social capital is more likely to produce positive outcomes due to it being less likely to produce destructive outcomes such as criminal activity. Further conceptual refinements of social capital have led to the introduction of 'linking' social capital (Woolcock, 2001; Stretzer and Woolcock, 2004). Linking social capital can be defined as the norms of respect and networks of trusting relationships between people who are interacting across explicitly formal or institutionalised power or authority gradients in society (Stretzer and Woolcock, 2004). This refinement to the concept thus allows a distinction between those social relationships which would otherwise be grouped together in 'bridging' forms, namely between those relationships that are indeed acting to 'bridge' individuals across horizontal dimensions as they are otherwise more or less equal in terms of their status and power, and those that connect people across vertical power differentials, particularly with regards to accessing public and private services (Stretzer and Woolcock, 2004). The notion of linking social capital is important with regards to poor communities where the nature and (lack of) extent of trust in formal institutions such as bankers, police, social workers will have a bearing on economic and social outcomes (Krishna, 2002). 
Social capital may impact on entrepreneurship both as an individual and collective resource (Westlund and Bolton, 2003), and through social interaction entrepreneurial activity can emerge and existing entrepreneurs can adapt to changes in the market (Seabright, 2004). At the local level, rates of entrepreneurship vary greatly across, as well as within, cities and regions (Glaeser et al, 2010). Localities which foster entrepreneurial dynamism harness economic growth, with a critical mass of businesses providing opportunities for employment, competition, and knowledge generation (Porter, 1995). Within cities, successful neighbourhoods need at first to 'feel safe' in order to harness entrepreneurship (Jacobs, 1961). Neighbourhoods which encourage informal contact at all hours of the day and night, harness the self-monitoring 'eyes on the street' necessary for feeling safe and for the emergence of informal networks of trust (Glaeser and Sacerdote, 2000). Clearly, trust plays a pivotal role in social networks (De Carolis and Saparito, 2006), and informal contact allows for potential coordination among individuals and assists in harnessing entrepreneurship (Glaeser and Sacerdote, 2000).

Effective institutions and a culture supportive of entrepreneurship make it possible for economic actors to take advantage of perceived opportunities (Minniti and Levesque, 2008). Cities with institutions conducive to enabling economic development are likely to increase their growth by attracting investment, skills and talent. Some examples include: local business regulations, which allows commercial activity to be efficient; the ease of doing business; local government initiatives; and ultimately, the perceptions of businesses and individuals in a city (Crouch et al., 2009; Rodríguez-Pose, 2013). Contributions from new institutional economics have recognised the temporal nature of institutions, with it argued that embedded informal institutions are likely to endure far longer than those associated with more formal governance mechanisms (Rafiqui, 2009; Williamson, 2000). In general, institutions introduced indigenously, and which evolve endogenously, are the most likely to persist over time, and are likely to be relatively 'sticky' as they will have evolved from pre-existing institutions and beliefs (Boettke and Fink, 2011). A growing school of research has identified the particular role of localised institutions in shaping entrepreneurship and the subsequent market orientation of firms (Fritsch and Kublina, 2015; Qian et al., 2013). Where formal institutions no longer support existing activities within a city, it is not beyond possibility that the prevailing informal institutions, as expressed in form of social capital, may actually strengthen to fill this gap (Huggins and Thompson, 2015).

Recent research on agglomeration economies has identified the role of social capital in the form of 'communication externalities', as important factors that sit alongside externalities pertaining from human capital (Charlot and Duranton, 2006). In this case, social capital within and across cities is likely to be regulated by a series of 'associational institutions' in the form of conventions with regard to collaboration and cooperation, especially associational business behaviour and norms of trust and collective action (Cooke and Morgan, 1998; Huggins and Thompson, 2014).Entrepreneurship can be selfreinforcing in nature and concentrates spatially because of the social environment as individuals follow societal clues and are influenced by what others have chosen to do (Minniti, 2005). Entrepreneurial activity can create its own feedback cycle, slowly moving society to a more entrepreneurial culture and in regions and locations with a high density of entrepreneurial activity examples of successful new venture creation offer role models people can conform to (Westlund et al, 2014). Indeed, the level and types of entrepreneurial activity within a place act as a neighbourhood effect, with role models and peers facilitating individual's decisions to found their own firms (Audretsch and Keilbach, 2004; Chavdarova, 2014). Place, therefore, can influence entrepreneurial activities via a shared culture or set of formal and informal rules (Werker and Athreye, 2004).

The literature demonstrates how social capital plays a moderating role between local character and culture of a place and the level of entrepreneurship, with different 
forms of social capital resulting in differing forms of entrepreneurship (Huggins and Thompson, 2015). Furthermore, our paper demonstrates that this is not a static affair, with social capital having different impacts at different points in the 'entrepreneurial cycle', from birth to being established to growth. As such, social capital can be considered to be dynamic and evolving.

\section{ENTREPRENEURSHIP AND SOCIAL CAPITAL IN DEPRIVED URBAN NEIGHBOURHOODS}

Deprived urban neighbourhoods are often characterized by low levels of entrepreneurship (Chatterton and Bradley, 2000; Huggins and Williams, 2009), with the rate of business startups in the 20 most deprived local authority areas in the UK being half the rate in the 20 most prosperous (Williams and Williams, 2011). Such differences may be explained by the presence of numerous barriers to entrepreneurship, including residents lacking the necessary business skills, a lack of appropriate access to finance, an absence of mentoring and advice, and a lack of role models (Slack, 2005; Rouse and Jayarwana, 2006; Welter et al, 2008; Williams and Williams, 2011). While such barriers are not exclusively faced by entrepreneurs in deprived urban neighbourhoods, they are likely to be more acute than elsewhere (OECD, 2003; Welter et al, 2008).

Despite the numerous barriers faced, the development of social capital has the potential to empower people to become entrepreneurial (Westlund and Bolton, 2003; Acs and Kallas, 2007) and deprived urban neighbourhoods with stable populations may have positive levels of 'bonding' social capital that exceeds the level of affluent areas (Evans et al, 2006). Trust can be built in a local neighbourhood through familiarity resulting from past experiences, repeated transactions and face-to-face contacts, and is particularly important in deprived areas (Welter et al, 2008). However, deprived communities are often considered to lack effective social capital (Middleton et al, 2005; Slack, 2005; Welter et al, 2008), or the capacity to benefit from it where it does exist (Evans et al, 2006). This absence is cited as being a potential barrier to entrepreneurship (Slack, 2005; Welter et al, 2008). Furthermore, a negative aspect of existing social capital may be that is overly biased towards bonding forms, resulting in localities that are insular and exclusionary (Evans et al, 2006; Middleton et al, 2005).

Affluent localities are often considered to contain high quality human capital, adequate financial capital and social capital and can therefore more readily take advantage of entrepreneurial opportunities (Acs and Kallas, 2007). Therefore, within urban environments, different cities, or localities within cities, often experience quite different entrepreneurial development. In more prosperous localities Florida's (2002) 'creative classes' may be attracted and retained by: better quality amenities and opportunities for social interaction (Mellander et al, 2010); job opportunities and the aesthetic beauty of the environment (Florida et al, 2010), and tolerance, particularly of those individuals associated with bohemian lifestyles (Florida, 2002; Florida et al, 2008). These creative individuals will bring in new ideas and knowledge, which will help to boost knowledge driven entrepreneurship. More deprived cities or localities within cities, on the other hand, experience relatively low levels of mobility and higher levels of unemployment (Morrison, 2005). This will tend to lead to low-tech entrepreneurship. In fact, Thompson et al (2010) suggest that the pattern may be amplified where those who successfully develop sustainable enterprises leave the deprived area to be replaced by those with weaker connections to the labour market and access to relevant knowledge.

Residents in low-income and challenging neighbourhoods may be deeply embedded in networks of mutual support (Schnell and Sofer 2003), providing free services for one another ranging from car repair to hairstyling, but these networks do not necessarily translate into a resource that can in turn be leveraged for economic benefit 
(Hays and Kogl, 2007). Furthermore, where social capital is utilized in deprived urban neighbourhoods, it is often considered to have a negative impact (Hogget, 1997; Atkinson and Kintrea, 2001; Middleton et al, 2005). For example, Hogget (1997) states that the network norms in deprived areas can be those associated with gangs and drugs, while Portes and Landolt (1996) state that there is considerable social capital in "ghetto areas", and that this can be manifested in inner-city youth gangs which work as social networks. Although Middleton et al (2005) consider that this may be an exaggeration, social capital may not always have positive impacts in deprived urban neighbourhoods and may be constraining rather than enabling (Atkinson and Kintrea, 2001).

In summary, the literature suggests that social capital is an important dimension in building capacity for entrepreneurship (Westlund and Bolton, 2003; Welter et al, 2008). As social capital is a spatial characteristic 'place' is critical in understanding how entrepreneurial opportunities emerge and are exploited (Westlund and Bolton, 2003). In deprived communities 'drag chains' may exist holding back entrepreneurship (Schumpeter, 1934; Westlund and Bolton, 2003). In comparison, affluent communities are more likely to contain high quality social capital (Acs and Kallas, 2007). Indeed, a range of evidence suggests that drag chains in the form of the underlying socio-spatial culture and institutional arrangements within a locality influence decision-making processes relating to entrepreneurship (Thornton, Ribeiro-Soriano, and Urbano 2011). The interaction of culture and entrepreneurship has potential ramifications at a number of differing levels, and one manifestation of a drag-chain is where the local community culture tends to dismissive of the individualism associated with entrepreneurial activities, with greater cultural value attached to collective endeavours (Huggins and Thompson, 2016). This cultural drag chain perspective represents an aggregate trait view, whereby cultures that establish a population with strong entrepreneurial values will generally result in the creation of more entrepreneurs (Uhlaner and Thurik 2007). A complementary institutional drag chain perspective is the legitimation or moral approval approach, whereby informal institutions makes entrepreneurial activities more or less acceptable and, as such, better or worse rewarded than other alternative forms of economic activity (Kibler, Kautonen, and Fink 2014). In essence, therefore, underlying local cultural and institutional constraints acts as the drag chains that may pull back and restrain entrepreneurial activity in particular places.

The types of social capital utilized and the returns associated with entrepreneurship, may result in entrepreneurial ventures being directed toward either productive or unproductive activities. In deprived urban neighbourhoods, entrepreneurial activities may be directed towards socially unproductive activities, including illegal or informal ventures, as social capital and societal drag chains lead to negative outcomes (Middleton et al, 2005). Indeed, rather than lacking an entrepreneurial culture per se, deprived areas may contain a 'hidden enterprise culture' whereby entrepreneurship is directed towards informal activities due to the barriers in place (Williams, 2006). This means that deprived areas do not lack entrepreneurship, but often the activity will be hidden from tax and regulatory authorities (Williams, 2010). The broad schematic framing our analysis of the role of place in moderating the association between entrepreneurship and social capital is summarized by the framework presented in Figure 1.

Figure 1 About Here

\section{THE STUDY AREA}

Our study focuses on the city of Leeds, which lies within the Yorkshire and Humber region in the north of England. As with the wider regional economy, Leeds has shifted from an industrial centre to a post-industrial economy focused on service industries as traditional 
manufacturing has declined (Williams and Williams, 2011). As such, it has experienced issues that are common to post-industrial spaces, and the conclusions of the study can be applied to other similar locations. The decline in employment in manufacturing has left a legacy of pockets of relative deprivation which is still being tackled today, and while some areas of the city have prospered as new jobs have been created, others still display persistent levels of economic and social deprivation. Leeds has a population of over 772,000 and is the largest centre of financial and business services outside London and has experienced strong economic growth in the last two decades (Leeds City Council, $2008,2009)$. However, this growth has not benefitted all areas, with approximately $20 \%$ of the city's population live in areas that are ranked among the most deprived in the UK (Williams and Williams, 2011). These areas have high levels of unemployment which are more than double the city's average, as well as exhibiting stark inequalities in educational achievement, house prices, health and crime (Williams and Williams, 2011). Unsurprisingly, levels of business start-ups are also low, and the contribution of smaller firms to job creation within the poorer areas is below the averages for the Leeds district and the region (Leeds City Council, 2007).

The deprived urban locality studied consists of the neighbourhoods of Chapeltown, Harehills, Beeston, Seacroft and West Leeds in the city of Leeds. The study focuses on deprived urban localities covering the 31 Super Output Areas (SOAs) within the city which feature in the most poorly performing $3 \%$ of SOAs nationally, encompassing a population of around 46,000 people (DCLG, 2006; Leeds City Council, 2008, 2009). SOAs are geographically designed for the collection and publication of small area statistics. The most deprived SOAs are calculated using seven 'domains of deprivation' which are: (1) income deprivation; (2) employment deprivation; (3) health deprivation and disability; (4) education, skills and training deprivation; (5) barriers to housing and services; (6) living environment deprivation; and (7) crime (DCLG, 2007). The domains are designed to measure the major features of deprivation, and not simply conditions experienced by a small number of people or areas (DCLG, 2007). These domains provide an appropriate definition of deprivation for the study.

\section{METHODS}

The methodology underpinning primary data collection and analysis consists of a quantitative survey of entrepreneurs and potential entrepreneurs and in-depth interviews with entrepreneurs operating in the study area. For the quantitative survey, a spatially stratified sampling technique was employed to select households within the study area for interview (Kitchen and Tate, 2001). If there were some 1000 households in an area, then the researcher called at every 10th household. If there was no response and/or an interview was refused, then the 11th household was visited, then the 9th, 12th, 8th and so on. This provided a spatially stratified sample of each district. In total 142 face-to-face interviews with working age residents were carried out. The interviews were carried out with individuals who either currently ran a business or plan to start one in future.

In order to explore key issues in further detail, respondents who participated in the survey of residents and who identified themselves as entrepreneurs were contacted and asked to take part in a follow-up in-depth interview. A total of 18 in-depth interviews were undertaken. The interviews were audio-taped with the respondent's consent to allow them to be fully transcribed and analysed. The approach allowed key themes to emerge from the interviews rather than being imposed by the researcher. The interviews explored the types of businesses set up and the support, advice and guidance the entrepreneurs had received. A qualitative approach was appropriate because this stage of the research dealt with soft issues, which are not amenable to quantification (Hammersley, 1992; Jack and Anderson, 2002). 
In-depth interviews allow the entrepreneur to describe what they do, how, why, when and where (Gilmore and Carson, 2007). Qualitative interviews allow the "everydayness" of entrepreneurship to be explored (Wigren, 2007). Examining "everydayness" is particularly important as this moves analysis away from a focus on the "ideal-type" of individual, which can exclude typical individuals, towards a focus on the lived practicalities of entrepreneurs (Williams, 2006). As such, Wigren (2007, p. 394) states that qualitative approaches ensure that in entrepreneurship studies, the researcher can move beyond the "polished stories" told by and about entrepreneurs and manage to understand the reality of daily life of an entrepreneur or an entrepreneurial milieu.

Taken together, the combination of quantitative and qualitative methods adds strength to our study. Both quantitative and qualitative methods have weaknesses which are, to an extent, compensated for by the strengths of the other (Creswell, 2003). The strength of quantitative methods are that they produce factual and reliable outcome data that are generalisable to a larger population (Burton, 2000; Punch, 2004); while the strength of qualitative methods are that they generate rich and detailed data that allow the study participants' perspectives to be intact (Burton, 2000; Punch, 2004). The combination of approaches can be considered as the natural complement to traditional qualitative and quantitative research, and can provide deep and valuable insights (Blackburn and Smallbone, 2008; Welter and Lasch, 2008).

\section{RESULTS}

\section{Sources of social capital}

Survey respondents were initially asked which sources they had drawn upon or would expect to drawn upon when planning and developing their business. The results are presented in Table 1 which is delineated by strong ties, defined as those sources who share the same knowledge and contacts as the respondents, such as family and friends with whom there may be strong trust, and weak ties, defined as those sources outside the respondent's immediate circle of contacts - and may therefore allow access to a diverse pool of advice and information - such as acquaintances, customers, suppliers or colleagues (Granovetter, 1973; Burt, 1992).

\section{Table 1 About Here}

Table 1 shows that social capital in the form of interactions with family and friends is a key network resource utilized by entrepreneurs. These bonding forms of social capital, utilising strong ties of family and friends, are likely to be with sources sharing the same knowledge and contacts as the individuals themselves, and consequently may have limited usefulness (Granovetter, 1973; Burt, 1992; Bruderl and Preisendorfer, 1996). The results indicate that weaker ties are not used to the same extent, with little evidence that bridging forms of social capital are utilized. The in-depth interviews with entrepreneurs further explored the usage of bonding/bridging social capital and strong/weak ties. All of the entrepreneurs interviewed stated that family and friends were important in the development of their ventures, and were utilized at all stages of venture development. Informal support is viewed as very important in the development of entrepreneurial ideas and plans, with many respondents stating that they were encouraged and supported by friends and family from the genesis of their idea, through to the successful realisation of their venture, suggesting that entrepreneurs taken advantage of strong ties, echoed by the following: 
"I had an idea and bounced it around for a good couple of years with some of my family and friends. It was helpful for me to get their help because they were really honest with me. They told me about how I could develop my idea and improve it ... By getting that advice I think my idea improved." (Self-employed male ICT consultant)

"I thought I had a good idea but getting advice from my friends helped me think about more. It made me think about practical things like turning the idea into an actual business, and how to do some original marketing so I could stand out ... The conversations I had helped to improve my business." (Self-employed male electrician)

\section{Local embeddedness}

For many respondents, a key strength of their locality is its 'close-knit' nature, with many families having lived there for generations. In total, $49 \%$ of respondents had lived in the area all of their life, $31 \%$ had lived there most of their life, and $21 \%$ had lived in their area for less than 5 years (Table 2). This local embeddedness provides a network of family and friends who have grown-up within the same cultural environment over a number of generations. The social networks generated may also continue to be developed by the entrepreneurs and potential entrepreneurs, with 52\% stating that it was unlikely they would move out of the local area in the next 5 years (Table 3 ).

Table 2 About Here

Table 3 About Here

The embedded nature of the social networks in the locality was explored further in the indepth interviews, with interviewees indicating this as an important resource, i.e. social capital, to be drawn upon:

"In an area like this, everybody knows everybody. The people are friendly and you can rely on them ... A lot of my marketing is done by word-of-mouth and I know that people will recommend me. It is a close-knit community." (Selfemployed male web designer)

"I spent a lot of money on advertising when I first set up my business but it was a waste of money. I just thought that that was the thing you had to do to get a business going. But really, I would have been much better off just relying on word-of-mouth. I don't think I was confident that word would spread around about what I was doing but it really has. People recommend me to their friends and family, then they recommend me to people they know. " (Self-employed female physiotherapist)

Interviewees also emphasized the importance of utilising social ties as part of their business strategy, which enabled them to build on their customer base. For some, entrepreneurial activity started as a service for family and/or friends, and then grew into a more formal business through contacts with other people in the area. For example:

“I just started doing things for friends. I didn't really think about it as a business for a while, even though they paid me a little bit ... But after a while I thought if my friends are willing to pay me, then why won't other people? So I started 
asking my friends to ask their friends and family and things went from there." (Self-employed female fashion designer)

I have lived here nearly all my life so I know a lot of people. That's how I got going, by spreading the word through my friends and people I knew, and people that my friends knew. That gave meant I could get my sales going as it meant I was accessing a good number of people ... In the early days I think some of my family and friends bought things off me just to help me out and it really did. It got me going and acted as some free advertising." (Self-employed female fashion retailer)

The quotes demonstrate that informal activity is not always necessarily negative. The interviewees had often started their businesses on an informal basis, and used their bonding ties to enable them to develop and grow the business further. Furthermore, in addition to business advice and guidance, interviewees considered that their friends and family were supportive of their decisions to become entrepreneurs and their aims to grow. This support was provided despite a lack of direct of experience of entrepreneurship among the majority of the friends and family utilized as a resource. In this sense, rather than social interactions and norms being 'drag chains' which hold back entrepreneurs (Schumpeter, 1934; Westlund and Bolton, 2003), social capital supported enterprise development:

"Some people around here start their own businesses, but there aren't any entrepreneurs in my family or among my friends. They are all either working for someone or unemployed. I suppose me setting up my own business was a little unusual but I had a lot of support." (Self-employed female physiotherapist)

\section{Benefits of social capital}

In general, the main benefit of social capital generated as a result of the specificities of a location is the informal support and advice which can be accessed relatively readily, with survey respondents stating that their family and friends were in close proximity and acted as a valuable resource (Table 4). Respondents who stated that they live in a close-knit community (31\%) explained that high levels of trust created business opportunities either through extending their customer and/or supplier base, or through being able to draw on expertise from others.

\section{Table 4 About Here}

Knowing an entrepreneur can encourage others to become self-employed as entrepreneurship is self-reinforcing (Minniti, 2005). Within deprived communities an absence of role models can negatively impact on levels of entrepreneurship (Williams and Williams, 2011). The respondents recognized the importance of knowing someone who had started their own business as they could provide inspiration, confidence and support, although only $12 \%$ stated that there are role models in their community to inspire others. Nevertheless, some entrepreneurs stated that they were able to gain advice from other local entrepreneurs. For example:

"It's really good if you know people who have set up their own business. It means you can get advice off them. When I decided to start-up I had loads of questions and things I was worried about, but I spoke to a few friends who had been through it and they gave me advice... There have been times when I have 
wanted to quit but friends and family have convinced me to keep going and not give up." (Self-employed female photographer)

"My auntie had her own business so I thought if she could do it then I could do it too. It gave me confidence." (Self-employed female physiotherapist)

"I knew other people who had started their own businesses so I could get their advice. It made it seem more achievable. I haven't got advice as much I could have really, but I know it is always there ... Friends and family support is really important. It has been invaluable. They have encouraged me, and have lent me money when I needed." (Self-employed male business consultant)

Clearly, knowing other entrepreneurs has been effective in encouraging some entrepreneurs. Using local entrepreneurs as role models may be an effective method of further harnessing entrepreneurial activity in deprived communities, and may also assist in harnessing entrepreneurship among young people in deprived communities. Respondents recognized that often young people in their area were unaware of entrepreneurial opportunities that may be available:

"Young people don't necessarily know what opportunities are available to them. A lot of them wouldn't consider setting up their own business. They just wouldn't consider it even if in reality they could make a good go of it." (Self-employed male ICT consultant)

"If you are young and ambitious you can get dragged down in an area like this. If you try hard or want to do well you get frowned on. They need strong role models to make them more ambitious." (Self-employed male photographer)

While societal 'drag chains' (Schumpeter, 1934; Westlund and Bolton, 2003) had not held back the entrepreneurs interviewed, it is clear that some entrepreneurs considered that they may hold back other people living in deprived communities. As social capital may be constraining rather than enabling (Atkinson and Kintrea, 2001), the survey explored perceptions of the potential social network 'drag chains' (Table 5). The key social factors constraining entrepreneurship are considered to be crime/anti-social behaviour and a lack of support/role models. The low expectations of peers is also seen as a potential drag chain on entrepreneurship, while opportunities to exploit illegal or informal economic activities may have a negative impact on social capital. This indicates that underlying socio-spatial culture and local informal institutions are likely to influence entrepreneurship, in particular low levels of trust and rent-seeking social capital among a cohort of the local population potentially pull individuals away from engaging in productive entrepreneurship. Clearly, social ties and 'role models' are in existence, but their demonstration effect do not produce the types of cultural values and institutional environment that either endorses or legitimizes entrepreneurship. The perception on the role of crime adds to a growing body of evidence suggesting that a lack of adherence to accepted social rules - either formal or informal - is negatively associated with a positive and productive local entrepreneurial culture (Huggins and Thompson, 2015; 2016).

\section{Table 5 About Here}

In addition to advice, support and guidance, some entrepreneurs had also utilized the strong ties of their family and friends in financing their businesses. Eight of the 
entrepreneurs had borrowed finance from family and friends, and as their ventures were small they did not require large investments from these individuals:

"I didn't really need a lot of money when I started. I had saved some up from my employment but it wasn't enough so I borrowed a few thousand pounds of a member of my family." (Self-employed female fashion designer)

"I work from home so I didn't need a lot of cash to start-up ... I just borrowed a few hundred pounds from a friend to help my buy equipment." (Self-employed male web designer)

\section{DISCUSSION}

As the above findings illustrate, the social capital generated within a particular place is intrinsically linked to how entrepreneurship develops in these places, in this case a deprived urban locality. However, the link between place, social capital and entrepreneurship across deprived and affluent communities will differ according to the nature of their social capital endowments, which will in turn influence the level and type of entrepreneurship which emerges (Figure 1). In relatively deprived localities, strong ties of family and friends are key sources of social capital which are highly valued by local entrepreneurs. Although deprived communities can be considered in one aspect to lack social capital associated with business and other inter-organisational networks - as well as the financial resources to engage in such networks (Slack, 205; Welter et al, 2008), entrepreneurs in these communities instead invested in local social networks that positively contribute to their entrepreneurial activities. However, these social networks and the strong ties they engender run the risk of producing increasingly less marginal utility as their usefulness declines, hampering the growth potential of the entrepreneurial ventures (Granovetter, 1973; Burt, 1992; Bruderl and Preisendorfer, 1996). As the above findings indicate, social capital can direct people towards informal activity. Indeed, given the relatively large amount of informal entrepreneurship which exists in deprived communities this may constitute a type of social capital (Evans et al, 2006). Indeed, informal activity may be a building block towards a formal venture, with bonding ties utilised to enable entrepreneurs to develop and grow the business.

The summary responses in Table 6 demonstrate that knowing an entrepreneur within one's own social network can act as a spur towards launching an entrepreneurial venture. For many entrepreneurs inspiration was gained from friends or family, or local people they knew. This is consistent with the view that potential entrepreneurs are more influenced by successful business people based locally, rather than, for example, nationally-renowned entrepreneurs (Hindle and Klyver, 2007). Entrepreneurship can be seen as not only as market entry of new, possibly innovative, firms, but also imitative entries into new markets, as it does not necessarily demand originality or invention (Kirzner, 1997). As such, role models can lead to others trying to emulate or imitate the behaviour of entrepreneurs and launch their own ventures. Therefore, a feedback cycle exists, although within deprived communities an absence of role models can negatively impact on levels of entrepreneurship (Evans et al, 2006). While entrepreneurs often gained inspiration from a family member acting as a role model, there is recognition among the entrepreneurs that the deprived urban locality lacks a wider range of role models who may positively influence people.

This lack of role models may inhibit entrepreneurial attitudes and aspirations among young people in the local area, and although societal drag chains had not held back the entrepreneurs taking part in the in-depth interviews, there was recognition by entrepreneurs that such drag chains exist. Similarly, some of the issues cited by 
respondents to the wider survey - the prevalence of crime/anti-social behaviour, a lack of role models, lack of support, low expectations of peers and opportunities in informal entrepreneurial activities (Table 5) - further act as potential drag chains in deprived urban neighbourhoods.

\section{CONCLUSIONS}

The concept of social capital has evolved to mean different things to different disciplines and at the same time has often overlooked the situational context in which it occurs (Staber, 2007). However, by reducing the concept to its key element - the nature of social relations - and examining a context in which entrepreneurship is weak, this paper has shown that it is an important factor in building capacity for entrepreneurial activity and has a pronounced place based dimension even in a deprived urban setting. Social capital clearly has a strong association with patterns of entrepreneurship in such settings, although the potential impacts are both positive and negative. The paper sought to examine the extent that social capital facilitates or constrains entrepreneurship in deprived localities, and shows that the forms of social capital are found to differ from those more prevalent in affluent localities, with bonding social capital being the key facilitator of entrepreneurship in deprived settings. This may help in the early stages of venture development, but may become a constraint over time.

Within deprived urban neighbourhoods, social capital can empower individuals to engage in entrepreneurship. In this sense, social capital is not found to act as drag chains holding back entrepreneurship, with entrepreneurs potentially benefiting from local social capital generated within a locality lacking many of advantages afforded to more leading localities which have often drawn upon as case studies to extol the entrepreneurial and economic virtues of local social capital. The general perception of entrepreneurs in the deprived locality is that they can benefit from established relationships by staying in their local area, and conversely if they had established businesses outside of their local area they would not have been able to take advantage of local networks. This suggest that the 'network compensation hypothesis' - whereby entrepreneurs with a less favourable human capital profile and with restricted financial resources try harder to mobilize their social contacts and receive more support out of their network (Bruderl and Preisendorfer, 1996) - can be applied within a place-based context.

In examining the different forms of social capital, the paper shows that entrepreneurs in deprived urban neighbourhoods appear to mobilize resources to utilize social capital particularly through bonding forms based on close ties between homogeneous groups such as close friends and business associates sharing similar characteristics and cultural background. These may have limited usefulness as they will share the same knowledge and contacts as the entrepreneurs themselves. However, bridging forms of social capital - referring to ties which connect people between socially heterogeneous groups, and which can link entrepreneurs, business organisations and local authorities horizontally at the local level and vertically across different spatial levels - are not being utilized. Consequently, social capital among entrepreneurs in deprived localities can be characterized by strong bonds but weak bridges. In order to maximise the potential of their ventures, these entrepreneurs will potentially benefit from expanding their social capital to utilize weak ties that are outside their immediate circle of contacts. However, entrepreneurs can draw on bonding social capital to start informal entrepreneurial activity, which can then provide a route to developing a more formal business as experience and knowledge is gained.

As Woolcock (1998) states, the challenge for development theorists and policymakers alike is to identify the mechanisms that create, nurture, and sustain the types and combinations of social relationships conducive to building dynamic participatory 
societies, sustainable equitable economies, and accountable states. Whilst acknowledging the importance of social capital and trust to development, it is equally important to understand the mechanisms that facilitate its creation, which would seem to be firmly rooted in the cultural characteristics of place (Huggins and Thompson, 2015). The informal institutions associated with social capital may sometimes be in conflict with national institutions, resulting in unintended consequences (Thornton, 1999). Where there is conflict between formal and informal institutions North (1990) suggests that informal institutions and culture will determine underlying behavior to the greatest extent. Given differing physical and industrial environments there is no reason to assume that regional or local social capital will be uniformly compatible or incompatible with the prevailing formal institutions. This suggests that policies developed to alter only formal institutions in lagging urban areas may only have limited success, as the evolution of informal institutions is likely to be relatively slow and will limit the influence of the formal changes achieved (North, 2005).

From the perspective of policy, social capital, and the associated role of culture and institutions, are central to emerging debates concerning the extent to which intervention should be either place-based or place-neutral (Garcilazo, 2011; Barca et al., 2012). Whilst place-neutral advocates promote the role of aspatial 'people-based' policies (Gill, 2010), place-based approaches highlight the importance of the interactions between place-based communities, institutions and geography for development and development policies, requiring researchers 'to explicitly consider the specifics of the local and wider regional context' (Barca et al., 2012, p. 140). Advocates of place-based policy approaches argue that a spatially decentralized political base can allow for differentiation in urban and regional economic policies, including entrepreneurship, and in a normative sense policy should seek to encourage diversity and experimentation across regions (Morgan, 1997; James, 2011). Promoting localised social capital is a potentially useful approach for policy makers, with bridging forms developed by giving support to community groups, and bonding forms utilised to help to support the interests of the local business community (Williams and Williams, 2011). In order to encourage individuals in more deprived areas to consider entrepreneurial careers there is a need to make individuals aware of where advice might be sought and help provided to develop these relationships, alongside the use of community entrepreneurs to act as role models (Malecki, 2012) and there are able to promote enterprising capabilities through the education system which may have the long-term potential to positively impact on residents' attitudes, including young people. Policy should focus on role models from the local community which entrepreneurs can be more influenced by rather nationally-renowned entrepreneurs from outside (Hindle and Klyver, 2007). Yet at the same time, although entrepreneurship has often been identified as a possible solution for urban areas with higher levels of deprivation (Lyon et al., 2002), the evidence suggests that this will meet with limited success. The underlying social capital is likely to bear the scars of its previous economic activities and these are likely to be more associated with low-value entrepreneurship, potentially perpetuating the cycle of less entrepreneurial intensive activities (Mueller, 2006; Fritsch and Mueller, 2005; Andersson and Koster, 2011). In particular, there may be a danger of supporting the type of enterprise activities that generate low growth temporary shelter from unemployment (Shane, 2009). Policy makers should be aware that entrepreneurship is not a magic bullet which can alleviate a broad range of economic and social problems (Blackburn and Ram, 2006). While sparkling the 'entrepreneurial pixie dust' is appealing (Peck, 2016), reversing historically low levels of entrepreneurship in deprived localities brings significant challenges, and success can only be achieved if policy is undertaken alongside other economic and social policies, particularly education initiatives, focused on deprivation. 


\section{References}

Acs, ZJ, and K. Kallas (2007) State of literature on small to medium-size enterprises and entrepreneurship in low income communities. Max Planck Institute Discussion Papers on Entrepreneurship, Growth and Public Policy, 0307.

Adler, P. and S.W. Kwon (2002) Social capital: Prospects for a new concept. Academy of Management Review 27(1) 17-40

Andersson, M., and S. Koster (2011) Sources of persistence in regional start-up rates evidence from Sweden. Journal of Economic Geography, 11 (1): 179-201.

Atkinson, R. and K. Kintrea (2001) Disentangling Area Effects: Evidence from Deprived and Non-deprived Neighbourhoods. Urban Studies 38(12), 2277-2298

Audretsch, D.B. and M. Fritsch (2002) Growth regimes over time and space. Regional Studies, 36(2), 113-124

Audretsch, D.B., W. Bonte, M. Keilbach (2008) Entrepreneurship capital and its impact on knowledge diffusion and economic performance. Journal of Business Venturing, 23(6), 687-698.

Audretsch, DB and M. Keilbach (2004) Entrepreneurship and regional growth: an evolutionary interpretation. Journal of Evolutionary Economics, 14(5), 605-616.

Barca F., McCann P. and A. Rodríguez-Pose (2012) The case for regional development intervention: place-based versus place-neutral approaches. Journal of Regional Science $52,134-152$.

Baumol, W.J. (1990) Entrepreneurship: Productive, Unproductive and Destructive. Journal of Political Economy, 98(5), 892-921

Becker, G.S. and K.M. Murphy (2000) Social economics: Market behavior in a social environment. Belknap Press, Cambridge, MA.

Beugelsdijk S and T. Van Schaik (2005) Differences in social capital between 54 Western European regions. Regional Studies 39(8): 1053-1064

Blackburn, R.A. and Ram, M. (2006) Fix or fixation? The contributions and limitations of entrepreneurship and small firms to combating social exclusion. Entrepreneurship and Regional Development, 18(1), 73-89

Blackburn, R.A. and Smallbone, D. (2008) Researching Small Firms and Entrepreneurship in the U.K.: Developments and Distinctiveness. Entrepreneurship Theory and Practice, 32(2), 267-288.

Boettke, P. and A. Fink (2011) Institutions first. Journal of Institutional Economics, 7 (4), 499-504.

Bourdieu, P. (1986) The forms of capital, in Richardson J. G. (Ed.) Handbook of Theory and Research for the Sociology of Education, pp. 241-258. Greenwood, New York, NY 
Bruderl, J. and P. Preisendorfer (1996) Network Support and the Success of Newly Founded Businesses. Small Business Economics 10(3), 213-225

Burt, R.S. (1992) Structural Holes. The Social Structure of Competition. Harvard University Press, Cambridge, MA.

Burt, R.S. (1997) The contingent value of social capital. Administrative Science Quarterly 42(2) 339-365

Burton, D. (2000) Research Training for Social Scientists. Sage, London.

Capello, R. Faggian (2005) Collective learning and relational capital in local innovation processes. Regional Studies 39 75-87

Charlot, S. and Duranton, G. (2006) Cities and workplace communication: some quantitative French evidence Urban Studies, 43, 1365-1394

Carree, M. and Thurik, A.R. (2006) "Understanding the role of entrepreneurship for economic growth" in The Handbook Entrepreneurship and Economic Growth (International Library of Entrepreneurship Series) In MA, Carree, AR, Thurik (eds) Edward Elgar, Cheltenham, p. ix-xix.

Chatterton, P. and D. Bradley (2000) Bringing Britain Together? The limitations of area based regeneration policies in addressing deprivation. Local Economy 15(2) 98-111

Chavdarova, T. (2014) Risky businesses? Young people in informal self-employment in Sofia. International Journal of Urban and Regional Research, 38(6), 2060-2077

Conway S and F. Steward (2009) Managing and Shaping Innovation. Oxford: Oxford University Press

Cooke, P. and Morgan, K. (1998) The associational economy: firms, regions, and innovation. Oxford: Oxford University Press.

Corcoran, M.P. (2006) The Challenge of Urban Regeneration in Deprived European Neighbourhoods: a Partnership Approach. The Economic and Social Review 37(3), 399422

Creswell, J.W. (2003) Research Design: Qualitative, Quantitative and Mixed Method Approaches. Sage, London.

Crouch, C., Schröder, M., and Voelzkow, H. (2009) Regional and sectoral varieties of capitalism. Economy and Society, 38, 654-678.

Dasgupta P (2003) Social capital and economic performance: Analytics. In: Serageldin I and Dasgupta P (eds) Social Capital: A Multifaceted Perspective. Washington, DC: World Bank, pp. 238-257.

Dasgupta P (2005) The economics of social capital. Economic Record 81(s1): S2-S21

Davidsson, P., and B. Honig (2003) The role of social and human capital among nascent entrepreneurs. Journal of Business Venturing, 18(3), 301-331. 
De Carolis, D. and P. Saparito (2006) Social capital, cognition and entrepreneurial opportunities: A theoretical framework. Entrepreneurship: Theory and Practice 30(1) 4156

Department of Communities and Local Government, 2006, Local Enterprise Growth Initiative, Round Two: Factsheets. HMSO, London

Evans, M. D. North, S. Syrett, I, Sanderson and C.C. Williams (2006) The Economies of Deprived Neighbourhoods: Summary of Research Department of Communities and Local Government, HMSO, London

Evans, M. and S. Syrett (2007) Generating Social Capital? Collaborative Relations, the Social Economy and Local Development Journal of European Urban and Regional Studies 14(1) 55-74

Fletcher D.R. (2008) Tackling concentrations of worklessness: highlighting the limits of work-focused organisational cultures in the UK. Environment and Planning $C$ : Government and Policy, 26(3), 563-582.

Florida, R. (2002). The Rise of the Creative Class and How It's Transforming Work, Life, Community and Everyday Life. New York, NY: Basic Books.

Florida, R., Mellander, C., and Stolarick, K. (2008). Inside the black box of regional development - human capital, the creative class and tolerance. Journal of Economic Geography, 8 (5), 615-649.

Florida, R., C. Mellander, and K. Stolarick. (2011) Beautiful Places: The Role of Perceived Aesthetic Beauty in Community Satisfaction. Regional Studies, 45(1): 33-48.

Forrest, R and A. Kearns (2001) Social cohesion, social capital and the neighbourhood Urban Studies 38(12) 2125-2143

Fritsch, M. and Kublina, S. (2015) Entrepreneurship, Growth, Regional Growth Regimes, Jena Economic Research Papers 2015-002. Friedrich Schiller University Jena.

Fritsch, M., and Mueller, P. (2005). How persistent are regional start-up rates? An empirical analysis. Research of Technological Innovation, Management and Policy, 9, 7182.

Fukuyama, F. (2003) Social Capital and Civil Society. Washington, DC: International Monetary Fund

Garcilazo E. (2011) The evolution of place-based policies and the resurgence of geography in the process of economic development, Local Economy 26, 459-466.

Gill I. (2010) Regional Development Policies: Place-Based or People-Centred? OECD Regional Development Policy Division, Paris (available at: http://www.voxeu.org/index.php?q=node/5644). 
Gilmore, A. and D. Carson (2007) Qualitative methodologies for enterprise research in Innovative methodologies in enterprise research. In D, Hine, D, Carson (eds) Edward Elgar, Cheltenham pp. 33-53.

Glaeser, E.L. (2002) Learning in Cities Journal of Urban Economics 46(2) 254-277

Glaeser, E.L. H.D. Kallal, J.A. Scheinkman and A. Shleifer (1992) Growth in cities Journal of Political Economy 100(6) 1126-1152

Glaeser, E.L. and B. Sacerdote (2000) The Social Consequences of Housing Journal of Housing Economics 9(1/2) 1-23

Glaeser, E.L., S.S. Rosenthal and W.C. Strange (2010) Urban economics and entrepreneurship. Journal of Urban Economics 67(1) 1-14

Granovetter, M. (1973) The Strength of Weak Ties American Journal of Sociology 78(6), 1360-1380.

Granovetter, M. (1983) The Strength of Weak Ties: a network theory revisited Sociological Theory 1(1) 201-233

Granovetter, M. (1985) Economic Action and Social Structure: The Problem of Embeddedness The American Journal of Sociology 91(3) 481-510

Grant, R. and Baden-Fuller. C. (2004) A knowledge accessing theory of strategic alliances. Journal of Management Studies, 41 (1), 61-84.

Hammersley, M. (1992) What's Wrong with Ethnography? Methodological Explorations. Longman, London

Hays, R.A. and A.M. Kogl (2007) Neighborhood Attachment, Social Capital Building, and Political Participation: A Case Study of Low- and Moderate-Income Residents of Waterloo, Iowa Journal of Urban Affairs 29(2) 181-205

Hindle, K and K. Klyver (2007) Exploring the relationship between media coverage and participation in entrepreneurship: initial global evidence and research implications" International Entrepreneurship and Management Journal, 3(2), 217-242

Hoang, $\mathrm{H}$ and Antoncic, B. (2003) Network-based research in entrepreneurship: a critical review Journal of Business Venturing 18(2) 165-187

Hogget, P. (1997) Contested Communities: Experiences, Struggles and Policies Policy Press, Bristol

Huggins, R (2010) Forms of network resource: Knowledge access and the role of interfirm networks International Journal of Management Reviews, 12, 335-352.

Huggins, R. (2016) Capital, institutions and urban growth systems. Cambridge Journal of Regions, Economy and Society, 9, 443-463 
Huggins, R. and A. Johnston (2010) Knowledge Flow and Inter-Firm Networks: The Influence of Network Resources, Spatial Proximity, and Firm Size. Entrepreneurship and Regional Development, 22(5) 457-484.

Huggins, R. and P. Thompson (2014) Culture, entrepreneurship and uneven development: a spatial analysis. Entrepreneurship and Regional Development, 26 (9/10), 726-52.

Huggins, R. and Thompson, P. (2015) Culture and Place-Based Development: A SocioEconomic Analysis, Regional Studies, 49(1), 130-159

Huggins, R. and Thompson, P. (2016) Socio-spatial culture and entrepreneurship: some theoretical and empirical observations. Economic Geography, 92 (3), pp. 269-300

Huggins, R. and N. Williams (2009) Enterprise and public policy: a review of Labour government intervention in the United Kingdom Environment and Planning C: Government and Policy, 27(1) $19-41$

Huggins, R. and Williams, N. (2011) Entrepreneurship and Regional Competitiveness: The Role and Progression of Policy. Entrepreneurship and Regional Development, 23(9/10), 907-932.

Jacobs, J. (1961) The death and life of Great American Cities Vintage, New York

Jack, S.L. and A.R. Anderson (2002) The effects of embeddedness on the entrepreneurial process. Journal of Business Venturing 17(5), 467-487

James, A. (2011) Regional cultural economy: evolution and innovation, in Cooke P., Asheim B., Boschma R., Martin R., Schwartz D. and Tödtling F. (Eds) Handbook of Regional Innovation and Growth, pp. 246-264. Edward Elgar, Cheltenham

Johannisson, B., Ramirez-Pasillas, M. and Karlsson, G. (2002) The institutional embeddedness of local inter-firm networks: a leverage for business creation. Entrepreneurship and Regional Development, 14, 297-315.

Johnston, G. and J. Percy-Smith (2003) In Search of Social Capital Policy and Politics 31(3) 321-34

Kibler, E., Kautonen, T., and Fink, M. (2014) Regional social legitimacy of entrepreneurship: Implications for entrepreneurial intention and start-up behaviour. Regional Studies, 48 (6), 995-1015.

Kisfalvi, V. (2002) The entrepreneur's character, life issues, and strategy making: A field study Journal of Business Venturing 17(5), 489-518

Kitchen, R. and N. Tate (2001) Conducting Research in Human Geography: Theory, Practice and Methodology Prentice Hall, London

Kirzner, I.M. (2009) The alert and creative entrepreneur: a clarification Small Business Economics 32(2) 145-152

Krishna A. (2002) Active Social Capital: Tracing the Roots of Development and Democracy. New York: Columbia University Press 
Kwon, S. and P. Arenius (2010) Nations of entrepreneurs: A social capital perspective Journal of Business Venturing 25(3), 315-330

Lagendijk, A, and A. Lorentzen (2007) Proximity, knowledge and innovation in peripheral regions. On the intersection between geographical and organizational proximity European Planning Studies 15(4) 457-466

Leeds City Council (2008) Sharing the Success: Projects Directory Leeds City Council, Leeds http://www.leeds.gov.uk/files/Internet2007/2008/week18/inter 98ae4c51-3dc84ac4-9298-cf3f79b16ed6 288c22df-13bc-4a60-af9a-d6be8e293244.pdf

Leeds City Council (2009) Regeneration through enterprise is working Leeds City Council, Leeds

http://www.sharingthesuccess.co.uk/uploadedFiles/STS\%20midterm\%20report.pdf

Liñán, F. and Santos, F. J. (2007) 'Does social capital affect entrepreneurial intentions?', International Advances in Economic Research, 13 (4), 443-453.

Lippmann, S., \& Aldrich, H. (2015). A Rolling Stone Gathers Momentum: Generational Units, Collective Memory, and Entrepreneurship. Academy of Management Review, amr2014.

Lyon, F., Bertotti, M., Evans, M., Smallbone, D., Potts, G., \& Ramsden, P. (2002). Measuring enterprise impacts in deprived areas: Report to the Small Business Service. London: Centre for Enterprise and Economic Development Research (CEEDR).

Malecki, E.J. (2012) Regional social capital: Why it matters. Regional Studies, 46, 10231039

Mellander, C., Florida, R., \& Stolarick, K. (2010). Here to stay - the effects of community satisfaction on the decision to stay. Spatial Economic Analysis, 6 (1), 5-24.

Michael, S.C. and J.A. Pearce (2009) The need for innovation as a rationale for government involvement in entrepreneurship Entrepreneurship and Regional Development 21(3), 285-302

Middleton, A., R. Murie and R. Groves (2005) Social capital and neighbourhoods that work Urban Studies 42(10) 1711-1738

Minniti, M. (2005) Entrepreneurship and Network Externalities Journal of Economic Behavior and Organization 57(1) 1-27

Minniti, M. and M. Levesque (2008) Recent developments in the economics of entrepreneurship Journal of Business Venturing 23(6) 603-612

Monge, P.M. and N.S. Contractor (2003) Theories of Communication Networks (Oxford University Press, Oxford)

Morgan K. (1997) The learning region: institutions, innovation and regional renewal. Regional Studies, 31, 491-504. 
Morrison, P. S. (2005). Unemployment and urban labour markets. Urban Studies, 42 (12), 2261-2288.

Mueller, P. (2006) Entrepreneurship in the Region: Breeding Ground for Nascent Entrepreneurs? Small Business Economics 27(1) 41-58

Mueller, P. (2007) Exploiting Entrepreneurial Opportunities: The impact of entrepreneurship on growth Small Business Economics 28(4) 355-362

Murphy, L., Huggins, R. and Thompson, P. (2015) Social capital and innovation: A comparative analysis of regional policies. Environment and Planning C: Government and Policy, online first, DOI: 10.1177/0263777X15597448

North, D. C. (1990). Institutions, institutional change and economic performance. Cambridge: Cambridge University Press.

North, D. and D. Smallbone (2000) Innovative activity in SMEs and rural economic development: Some evidence from England European Planning Studies 8(1) 87-106

Onyx, J. and Leonard, R. (2010) The conversion of social capital into community development: an intervention in Australia's outback. International Journal of Urban and Regional Research, 34(2), 381-397

Organisation for Economic Co-operation and Development (2003) Entrepreneurship and Local Economic Development: Programme and Policy Recommendations OECD, Paris Ostrom E and Ahn TK (eds) (2003) Foundations of Social Capital. Cheltenham: Edward Elgar

Peck, J. (2016) Economic rationality meets celebrity urbanology: Exploring Edward Glaeser's city. International Journal of Urban and Regional Research, online first, DOI: 10.1111/1468-2427.12321

Pitt, M, (1998) A tale of two gladiators: 'reading' entrepreneurs as texts Organisational Studies 19(3) 387-414

Porter, M.E. (1995) The competitive advantage of the inner city Harvard Business Review, $7355-71$

Portes, A. (1998) Social capital: Its origins and applications in modern sociology Annual Review of Sociology 24(1) 1-24

Portes, A. and P. Landolt (1996) The Downside of Social Capital The American Prospect $26,18-21$

Punch, K.F. (2004) Introduction to Social Research. Sage, London.

Putnam, R. (1995) Bowling alone: America's declining social capital" Journal of Democracy 6(1) 65-78

Qian, H., Acs, Z. J., and R.R. Stough (2013). Regional systems of entrepreneurship: The nexus of human capital, knowledge and new firm formation. Journal of Economic Geography, 13(4), 559-587 
Rafiqui, P.S. (2009) Evolving economic landscapes: why new institutional economics matters for economic geography. Journal of Economic Geography 9 (3), 329-53.

Rodríguez-Pose, A. (2013) Do institutions matter for regional development? Regional Studies, 47 (7), 1034-47

Rouse, J. and D. Jayarwana (2006) The financing of disadvantaged entrepreneurs: Are enterprise programmes overcoming the finance gap? International Journal of Entrepreneurial Behaviour and Research 12(6) 388-400

Schnell, I. and M. Sofer (2003) Embedding entrepreneurship in social structure: IsraeliArab entrepreneurship. International Journal of Urban and Regional Research, 27(2), 300318

Schumpeter, J.A. (1934) The Theory of Economic Development Harvard University Press, Cambridge, MA

Seabright, P. (2004) The company of strangers: A natural history of economic life (Princeton University Press, Princeton)

Shane, S. (2009). Why encouraging more people to become entrepreneurs is bad public policy. Small Business Economics, 33(2), 141-149.

Slack, J. (2005) The New Entrepreneur Scholarships: self-employment as a means to tackle social deprivation Education and Training 47(6) 447-455

Sobel J (2002) Can we trust social capital? Journal of Economic Literature 40(1): 139-54

Staber, U. (2007) Contextualising research on social capital in regional clusters. International Journal of Urban and Regional Research, 31(3) 505-521

Steyaert, C. (1997) A qualitative methodology for process studies of entrepreneurship: creating local knowledge through stories International Studies of Management and Organisation 27(3) 13-33

Stretzer, S. and Woolcock, M. (2004) Health by association? Social capital, social theory, and the political economy of public health. International Journal of Epidemiology, 33(4), 650-667

Thornton, P. H. (1999) The sociology of entrepreneurship, Annual Review of Sociology, 25, 19-46

Thornton, P. H., Ribeiro-Soriano, D., and Urbano, D. (2011) Socio-cultural factors and entrepreneurial activity: An overview. International Small Business Journal 29(2):105-18.

Turok, I. (2004) Cities, Regions and Competitiveness" Regional Studies 38(9) 1069-1083

Uhlaner, L., and Thurik, R. 2007. Postmaterialism influencing total entrepreneurial activity across nations. Journal of Evolutionary Economics 17(2):161-85. 
Virkkala, S. (2007) Innovation and networking in peripheral areas: a case study of emergence and change in rural manufacturing European Planning Studies 15(4) 511-529

Welter, F. and Lasch, F. (2008) Entrepreneurship Research in Europe: Taking Stock and Looking Forward. Entrepreneurship Theory and Practice, 32(2) 241-248.

Welter, F. L. Trettin and U. Neumann (2008) Fostering Entrepreneurship in Distressed Urban Neighbourhoods International Entrepreneurship and Management Journal 4(2) 109-128

Wennekers, S. and A.R. Thurik (1999) Linking entrepreneurship and Economic Growth Small Business Economics 13(1) 27-55

Werker, C. and S. Athreye (2004) Marshall's disciples: knowledge and innovation driving regional economic development and growth Journal of Evolutionary Economics 14(5), 505-523

Westlund, H. and R. Bolton (2003) Local social capital and entrepreneurship Small Business Economics 21(2) 77-133

Westlund, H., Larsson, J. P., and Olsson, A. R. (2014) Start-ups and local entrepreneurial social capital in the municipalities of Sweden. Regional Studies 48(6):974-94

Wigren, C. (2007) Assessing the quality of qualitative research in entrepreneurship" in Handbook of Qualitative Research Methods in Entrepreneurship In H, Neergaard, JP, Ulhoi (eds.) Edward Elgar, Cheltenham pp. 383-405

Williams. C.C. (2006) The Hidden Enterprise Culture Edward Elgar, Cheltenham

Williams, C.C. (2010) 'Spatial variations in the hidden enterprise culture: some lessons from England', Entrepreneurship and Regional Development, 22(5), 403 - 423.

Williams, N. and C.C. Williams (2011) Tackling barriers to entrepreneurship in a deprived urban neighbourhood Local Economy 26(1), 30-42

Williamson, O. (2000): The New Institutional Economics: Taking Stock, Looking Ahead. Journal of Economic Literature, 38, 595-613.

Woolcock M (1998) Social capital and economic development: Toward a theoretical synthesis and policy framework. Theory and Society 27(2): 151-208.

Woolcock, M. (2001) The place of social capital in understanding social and economic outcomes, Canadian Journal of Policy Research, 2(1), 11-17

Woolcock M and Narayan D (2000) Social capital: Implications for development theory, research, and policy. World Bank Research Observer 15(2): 225-250

World Bank, 2000, World Development Report, 2000-2001 World Bank, Washington, DC 
Figure 1: Social capital, place, and entrepreneurship

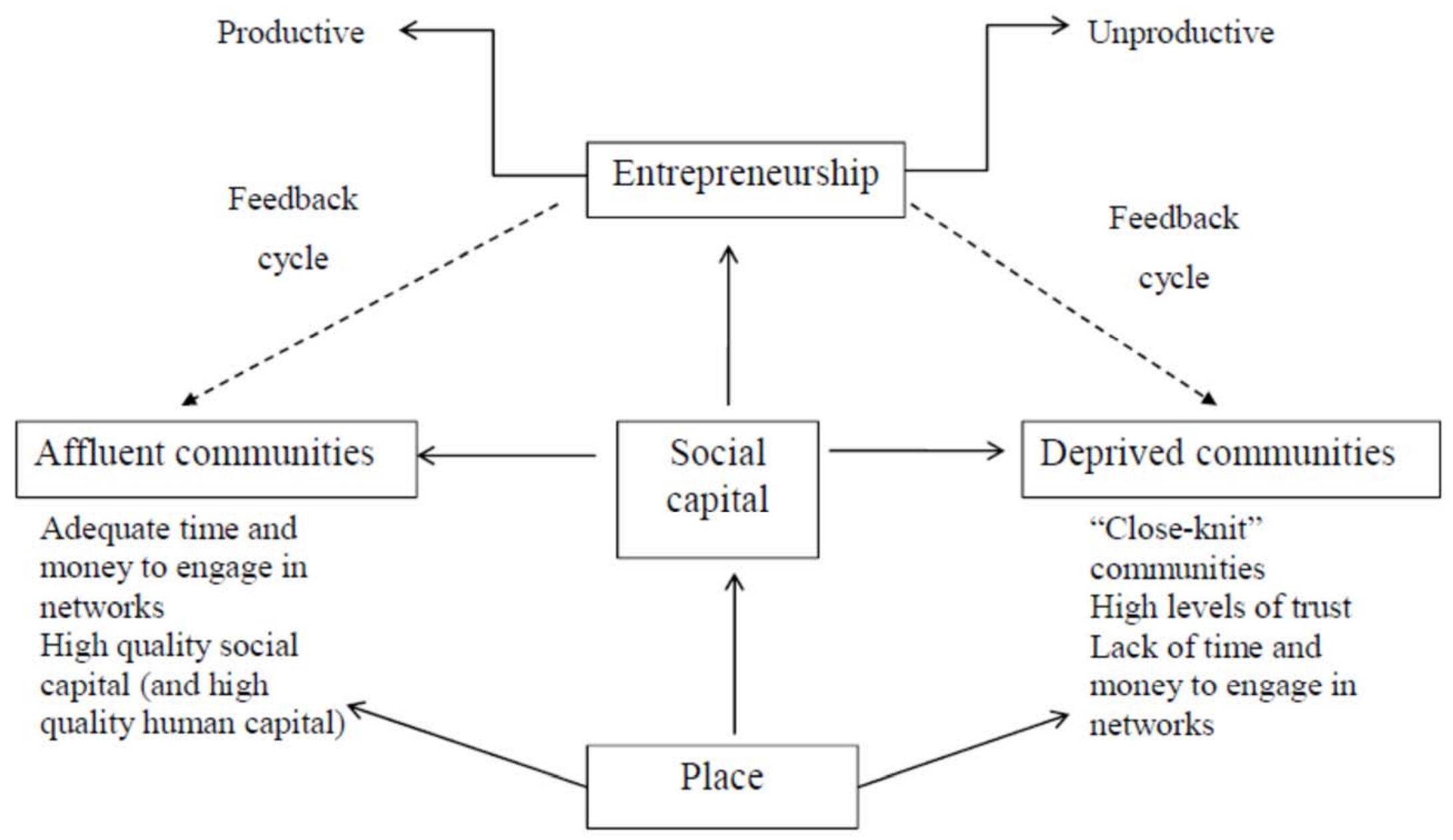


Table 1: Sources of social capital at the nascent stages of venture development

\begin{tabular}{llll}
\hline Strong ties & Percent & Weak ties & Percent \\
\hline Family & $58 \%(n=82)$ & Customers & $14 \%(n=19)$ \\
Friends & $44 \%(n=64)$ & Suppliers & $8 \%(n=11)$ \\
& & Colleagues & $8 \%(n=11)$ \\
\hline
\end{tabular}

Table 2: Length of time living in local area

\begin{tabular}{lccccc}
\hline Age group & $16-19$ & $20-24$ & $25-44$ & $45-59$ & Total \\
\hline All my life & 14 & 12 & 36 & 7 & $49 \%(n=69)$ \\
Most of my life & 6 & 7 & 28 & 3 & $31 \%(n=44)$ \\
Less than 5 years & 3 & 7 & 20 & 2 & $21 \%(n=29)$ \\
\hline Total & 23 & 23 & 84 & 12 & 142 \\
\hline
\end{tabular}

Table 3: Likelihood of moving out of local area in next 5 years

\begin{tabular}{lccccc}
\hline Age group & $16-19$ & $20-24$ & $25-44$ & $45-59$ & Total \\
\hline Very likely & 13 & 9 & 5 & 0 & $19 \% 9 n=27)$ \\
Likely & 7 & 9 & 8 & 0 & $17 \%(\mathrm{n}=24)$ \\
Unsure & 1 & 0 & 1 & 0 & $1 \%(\mathrm{n}=2)$ \\
Unlikely & 0 & 0 & 35 & 8 & $30 \%(\mathrm{n}=43)$ \\
Very unlikely & 0 & 1 & 27 & 3 & $22 \%(\mathrm{n}=31)$ \\
Don't know & 2 & 4 & 8 & 1 & $10 \%(\mathrm{n}=15)$ \\
\hline Total & 23 & 23 & 84 & 12 & 142 \\
\hline
\end{tabular}

Table 4: Benefits of place and social capital resources for entrepreneurial entures

\begin{tabular}{lc}
\hline & Percent \\
\hline There is informal support and advice available & $40 \%$ \\
It is a close-knit community & $31 \%$ \\
There are role models to inspire others & $12 \%$ \\
There is formal support and advice available & $10 \%$ \\
Don't know & $16 \%$ \\
\hline
\end{tabular}

Table 5: Factors constraining entrepreneurship

\begin{tabular}{lc}
\hline & Percent \\
\hline There is too much crime/anti-social behaviour & $29 \%$ \\
Lack of suitable role models & $25 \%$ \\
There is a lack of support/advice available & $19 \%$ \\
Low expectations of peers & $16 \%$ \\
Opportunity for informal entrepreneurial activity & $10 \%$ \\
Don't know & $19 \%$ \\
\hline
\end{tabular}


Table 6: Summary responses of entrepreneurs to key in-depth survey questions Question Summary of key responses

\begin{tabular}{|c|c|}
\hline $\begin{array}{l}\text { What network sources have you drawn } \\
\text { upon, or would expect to drawn upon, } \\
\text { when planning and developing your } \\
\text { business? }\end{array}$ & $\begin{array}{l}\text { Friends and family played an important } \\
\text { role in providing advice and guidance } \\
\text { which assisted in the development of } \\
\text { entrepreneurial ideas/ventures. } \\
\text { Family and friends provided a useful } \\
\text { sounding board for ideas, whether or not } \\
\text { the network contacts were/had been } \\
\text { entrepreneurs themselves. }\end{array}$ \\
\hline $\begin{array}{l}\text { In what ways has your locality impacted } \\
\text { on the development of your venture? }\end{array}$ & $\begin{array}{l}\text { Entrepreneurs stated that the area is } \\
\text { close-knit, which provides an extended } \\
\text { network of contacts via family, friends and } \\
\text { acquaintances. } \\
\text { Extended networks benefit the } \\
\text { entrepreneurs by providing a potential } \\
\text { customer and supplier base, as well as } \\
\text { generating marketing through word-of- } \\
\text { mouth. }\end{array}$ \\
\hline $\begin{array}{l}\text { What role did your social network play in } \\
\text { the development of your initial idea of an } \\
\text { entrepreneurial venture? }\end{array}$ & $\begin{array}{l}\text { The entrepreneurs utilized their social } \\
\text { network for gaining advice and guidance } \\
\text { regarding their initial entrepreneurial idea. } \\
\text { This assisted in modifying and improving } \\
\text { ideas before start-up. }\end{array}$ \\
\hline $\begin{array}{l}\text { What role did your social network play in } \\
\text { the start-up and growth of your business? }\end{array}$ & $\begin{array}{l}\text { Social networks played a key role in the } \\
\text { start-up and growth of the entrepreneurs' } \\
\text { businesses. } \\
\text { Friends, family and acquaintances } \\
\text { provided advice and guidance, as well as } \\
\text { an initial customer base. } \\
\text { For many of the respondents, the } \\
\text { businesses started by offering services } \\
\text { for friends and family, and then expanded } \\
\text { their customer base through a wider } \\
\text { range of acquaintances. } \\
\text { The close-knit nature of the local area } \\
\text { was seen to have assisted in expansion } \\
\text { of customers and suppliers through the } \\
\text { extended networks provided through } \\
\text { family, friends and acquaintances. } \\
\text { Word-of-mouth was seen as an effective } \\
\text { method of marketing. }\end{array}$ \\
\hline $\begin{array}{l}\text { Has your social network provided } \\
\text { effective role models for } \\
\text { entrepreneurship? }\end{array}$ & $\begin{array}{l}\text { The entrepreneurs have been positively } \\
\text { influenced by local people they know who } \\
\text { have set up their own businesses. }\end{array}$ \\
\hline
\end{tabular}




\begin{tabular}{|l|l|}
\hline & $\begin{array}{l}\text { In particular, family members who have } \\
\text { set up businesses were seen as particular } \\
\text { influential. They have influenced the } \\
\text { entrepreneurs to start their own } \\
\text { businesses by providing them with } \\
\text { confidence that they could also succeed. }\end{array}$ \\
& $\begin{array}{l}\text { Role models have provided } \\
\text { encouragement throughout the process of } \\
\text { the initial entrepreneurial idea, to start-up } \\
\text { and establishment/growth. }\end{array}$ \\
\hline $\begin{array}{l}\text { and } \\
\text { played a role in the financing of your } \\
\text { venture? }\end{array}$ & $\begin{array}{l}\text { Hower, there was recognition that their } \\
\text { area did not contain a wider range of role } \\
\text { models (for example, local business } \\
\text { people in the public) and that as such a } \\
\text { critical mass of role models who may } \\
\text { influence others to start businesses did } \\
\text { not exist. }\end{array}$ \\
\hline $\begin{array}{l}\text { Do you think that social networks have } \\
\text { the potential to act as a barrier to }\end{array}$ & $\begin{array}{l}\text { There was recognition among the } \\
\text { entrepreneurs that social networks could } \\
\text { have a negative influence which } \\
\text { could hinder entrepreneurship. }\end{array}$ \\
\hline $\begin{array}{l}\text { While not acting as a barrier to them, } \\
\text { negative perceptions and cultural } \\
\text { attitudes were seen to potentially hold } \\
\text { back young people from being } \\
\text { entrepreneurial. }\end{array}$ \\
\hline $\begin{array}{l}\text { The ventures started are all relatively } \\
\text { small and therefore did not require } \\
\text { significant external funding. Where } \\
\text { necessary the entrepreneurs were able to } \\
\text { borrow small amounts from family and } \\
\text { friends to help them start their } \\
\text { businesses. }\end{array}$ \\
\hline
\end{tabular}

